\title{
The Rise of Economics in Competition Policy: \\ A Canadian Perspective
}

MARCEL BOYER

THOMAS W. ROSS

RALPH A. WINTER

Allier savoir et décision 
2017s-26

\title{
The Rise of Economics in Competition Policy: A Canadian Perspective
}

\author{
Marcel Boyer, Thomas W. Ross, Ralph A. Winter
}

Série Scientifique
Scientific Series

Montréal

Décembre/December 2017

(C) 2017 Marcel Boyer, Thomas W. Ross, Ralph A. Winter. Tous droits réservés. All rights reserved. Reproduction partielle permise avec citation du document source, incluant la notice $@$. Short sections may be quoted without explicit permission, if full credit, including ${ }^{\circ}$ notice, is given to the source.

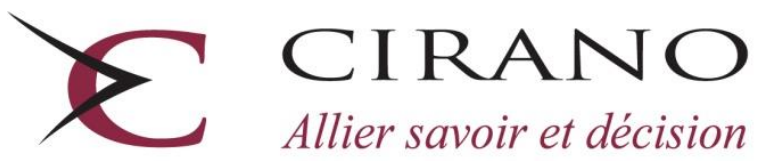

Centre interuniversitaire de recherche en analyse des organisations 


\section{CIRANO}

Le CIRANO est un organisme sans but lucratif constitué en vertu de la Loi des compagnies du Québec. Le financement de son infrastructure et de ses activités de recherche provient des cotisations de ses organisations-membres, d'une subvention d'infrastructure du gouvernement du Québec, de même que des subventions et mandats obtenus par ses équipes de recherche.

CIRANO is a private non-profit organization incorporated under the Quebec Companies Act. Its infrastructure and research activities are funded through fees paid by member organizations, an infrastructure grant from the government of Quebec, and grants and research mandates obtained by its research teams.

\section{Les partenaires du CIRANO}

\section{Partenaires corporatifs}

Autorité des marchés financiers

Banque de développement du Canada

Banque du Canada

Banque Laurentienne du Canada

Banque Nationale du Canada

Bell Canada

BMO Groupe financier

Caisse de dépôt et placement du Québec

Fédération des caisses Desjardins du Québec

Gaz Métro

Hydro-Québec

Innovation, Sciences et Développement économique

Intact

Investissements PSP

Ministère de l'Économie, de la Science et de l'Innovation

Ministère des Finances du Québec

Power Corporation du Canada

Rio Tinto

Ville de Montréal

\section{Partenaires universitaires}

École de technologie supérieure (ÉTS)

HEC Montréal

Institut national de la recherche scientifique (INRS)

McGill University

Polytechnique Montréal

Université Concordia

Université de Montréal

Université de Sherbrooke

Université du Québec

Université du Québec à Montréal

Université Laval

Le CIRANO collabore avec de nombreux centres et chaires de recherche universitaires dont on peut consulter la liste sur son site web.

Les cahiers de la série scientifique (CS) visent à rendre accessibles des résultats de recherche effectuée au CIRANO afin de susciter échanges et commentaires. Ces cahiers sont écrits dans le style des publications scientifiques. Les idées et les opinions émises sont sous l'unique responsabilité des auteurs et ne représentent pas nécessairement les positions du CIRANO ou de ses partenaires.

This paper presents research carried out at CIRANO and aims at encouraging discussion and comment. The observations and viewpoints expressed are the sole responsibility of the authors. They do not necessarily represent positions of CIRANO or its partners.

ISSN 2292-0838 (en ligne) 


\title{
The Rise of Economics in Competition Policy: A Canadian Perspective*
}

\author{
Marcel Boyert, Thomas W. Ross ${ }^{*}$, Ralph A. Winter ${ }^{\S}$
}

\begin{abstract}
Competition policy in Canada and elsewhere has changed remarkably over the last fifty years - in large measure due to advances in economics. In this article we trace the impact of developments in industrial organization on the three central areas of competition policy: cartels, single firm conduct and mergers. We focus on Canadian competition policy, but draw comparisons with developments in the United States and Europe.
\end{abstract}

\section{Résumé}

La politique de concurrence s'est remarquablement transformée au cours des derniers 50 ans au Canada, en grande partie à cause des avancées en science économique. Dans ce texte, nous retraçons l'impact des développements en organisation industrielle sur les trois zones centrales de la politique de concurrence : les cartels, la conduite de la firme, et les fusions. Nous mettons l'accent sur la politique de concurrence canadienne, mais en référant aux développements aux États-Unis et en Europe.

Codes JEL/JEL codes: L40, L41, K21

\footnotetext{
* The authors wish to thank the many friends and colleagues who have informed and shaped their thinking about competition policy over many years. That list is too long to reproduce here, but they would like to recognize the following for helpful discussions in the preparation of this paper: Martine Dagenais, Edward Iacobucci, Frank Mathewson, Donald McFetridge and Douglas West. They would also like to thank Jennifer Ng for very capable research assistance and acknowledge financial support for this work provided by CIRANO in Montréal and the Phelps Centre for the Study of Government and Business at the University of British Columbia.

${ }^{\dagger}$ CIRANO and Département de sciences économiques, Université de Montréal, Montréal, QC

¥ Sauder School of Business, University of British Columbia, Vancouver, BC

${ }^{\S}$ Sauder School of Business, University of British Columbia, Vancouver, BC
} 


\section{Introduction}

The integration of economics into competition policy has expanded dramatically over the fifty years that this journal has been published. Economists fifty years ago played a minor role in the antitrust world, typically collecting statistics under the direction of lawyers, and not heavily involved in formulating theories of cases. In 1971 Richard Posner characterized the economists in the Antitrust Division of the U.S. Department of Justice as "handmaidens to the lawyers, and rather neglected ones at that." ${ }^{11}$ And this in the antitrust jurisdiction most accepting of economic thinking and tools. Fast forward to 2015 and we see a case in which the Supreme Court of Canada rejected the government's challenge to a merger essentially on the grounds that the government had failed to provide econometric evidence of a parameter critical to the estimation of the impact of the merger on total surplus in the market. ${ }^{2}$

Economics is now the foundation of virtually every case in the central areas of competition policy: mergers, single firm conduct and cartels. Merger cases involve explicit economic models and involve simulations built on structural econometric models. Single firm conduct or abuse of dominance cases are now grounded in applied game theory. Even cartel law - traditionally involving fact-driven cases focussed on whether there is or is not evidence of meetings and communication - has benefited from the contributions of economists in strengthening detection and enforcement through screening models and leniency programs.

Canada's first competition law, An Act for the Prevention and Suppression of Combinations formed in Restraint of Trade ${ }^{3}$ was the first modern competition statute in the world, enacted in 1889, a year before the more famous U .S. Sherman Act. ${ }^{4}$ Both the Canadian and U.S. acts were directed at concerns that coordination across firms in many industries reduced competition and raised prices. ${ }^{5}$ The first Canadian law, a criminal statute, was poorly drafted, and had to undergo a series of revisions before it resembled the kind of competition policy framework we would

\footnotetext{
${ }^{1}$ Posner (1971) at p. 532.

${ }^{2}$ Tervita Corp. v Canada (Commissioner of Competition) 2015 SCC 3.

${ }^{3} 52$ Vict. C 41 (1889)

${ }^{4}$ An act to protect trade and commerce against unlawful restraints and monopolies, c. 647, 26. Stat.209 (1890).

${ }^{5}$ On the origins of the first Canadian law, see Halladay (2012) or, for more detail, Bliss (1973).
} 
recognize today. ${ }^{6}$ Merger and monopolization (abuse) provisions were added to the initial focus on collusion in 1910, and it was not until 1923 that a permanent enforcement body was established.

Reforms since 1923 recognized the need for fundamental changes in all three main areas of competition policy. It became clear that criminal law was inappropriate to the review of mergers and single firm conduct cases. An early requirement in cartel cases to establish an "undue lessening of competition" was problematic, in contrast to the per se law against price-fixing elsewhere. And economists began to question the treatment of various vertical agreements - the per se illegality of resale price maintenance for example.

Reform took place in three stages: in amendments taking effect in 1976; in the passage of the Competition Act of 1986; and then with amendments passed in 2009. The result is a Canadian law that generally reflects best practices and relatively sophisticated economic thinking. Mergers, single firm conduct and a variety of vertical arrangements are subject to civil/administrative review by an expert Competition Tribunal. Mergers that are shown to reduce competition can nevertheless be permitted if they improve market efficiency. Canada now has the strongest efficiency defense of mergers among OECD countries. Some of the rules on vertical restraints have been appropriately relaxed or even removed entirely. Naked price fixing - still a criminal offence - is subject to a clear per se prohibition without an "undueness" test. Joint ventures, strategic alliances and other potentially efficient agreements between competitors are now reviewed under noncriminal proceedings in a way similar to mergers.

This new, economically literate, competition law in Canada has been complemented by enforcement improvements guided by economic theory and techniques that can sort out the competitive and efficient from the anticompetitive and inefficient arrangements and conduct. The greater role for economists is reflected in the number of economists with advanced training employed by competition agencies. The Canadian Competition Bureau now employs a dozen economists with training to the doctoral level; the two U.S. enforcement agencies, the Department of Justice and the Federal Trade Commission, employ about 130 Ph.D. economists;

\footnotetext{
${ }^{6}$ On the original 1889 law Bliss (1987, p. 362) said: "The 1889 law was pious anti-monopoly posturing that had no effect on anything." On the subsequent evolution of the Canadian law and policy see Ross (1998) and, especially, the references cited therein.
} 
and the Chief Competition Economist of the European Commission now leads a team with more than 25 economists.

This evolution in the law has followed both changes in underlying economic ideas and a growing influence of existing ideas. What are these developments in economics and how have these ideas become incorporated in the foundations of the law?

In the following we trace the developments in competition economics and industrial organization generally with a focus on how these have been reflected in Canadian competition policy. We divide our efforts into the three major areas identified above: cartels (Section II), single firm conduct (Section III) and mergers (Section IV). Section V offers our views on elements of Canadian competition law still in need of attention

\section{Cartels}

The harm from cartel behaviour is the most clearly established proposition in the economics of competition policy. The idea that cartels raise prices to the detriment of consumers was understood from the start of our competition policy in 1889, and the policy towards cartels has never been controversial. In September 2012, for example, the Canadian Commissioner of Competition noted that "The most egregious harm results from criminal cartels. There's really no debating that point. There is no possible pro-competitive justification for competitors getting together to fix prices, to allocate markets among themselves or restrict output". ${ }^{7}$

With such a consensus over the basis for cartel policy, it might be supposed that economics has had nothing to add over the past 50 years. Indeed, because price-fixing is per se illegal in most jurisdictions around the world, cartel enforcement is largely fact driven. In any particular case, did price-fixing occur or not? Traditionally, in most jurisdictions including the U.S. there was no need for economic analysis in cartel cases because the issue was simply whether evidence supported the conclusion of explicit cartel coordination.

The link between cartel policy and economic foundations has not been quite so simple in Canada. Until 2010 price fixing was not per se illegal but rather illegal if it had the effect of "unduly" lessening competition. Courts struggled with the interpretation of the undueness

\footnotetext{
${ }^{7}$ Isfeld (2012)
} 
requirement. Economists had significant influence in promoting a two-pronged approach that distinguished between naked cartels and cooperation between competitors, in strategic alliance and joint ventures for example, that can be beneficial and should not be caught up in anti-cartel law. This dual track approach was formally adopted in Canadian competition policy with amendments to the Competition Act in 2010.

Beyond this development economists have had important roles in three areas of competition policy towards cartels; (1) screening for cartels, an area where the economics of distinguishing signals of collusion from competitive signals can be subtle; (2) the analysis of practices that facilitate collusion; and (3) the leniency and compliance programs, an area where policy has become sharper and much more productive.

\section{The Dual-Track Approach to Cartel Policy}

The amendments that produced the Competition Act in 1986 focused on the merger and singlefirm conduct provisions. In contrast, conspiracy law had been a relative success story: between 1889 and 1987 the Crown won 92 of the 126 conspiracy cases that went to trial. ${ }^{8}$ This impressive success rate began to slide, however, with only 32 of 51 cases prosecuted between 1980 and 2000 under s.45 (conspiracy) reaching a guilty plea or conviction. ${ }^{9}$ Of the remaining, 11 were discharged or acquitted for reasons related to the undueness requirement.

The challenges in the conspiracy provisions of the Competition Act attracted the attention of competition policy professionals. Kennish and Ross (1997), among others, pointed out that the law suffered from two problems. ${ }^{10}$ On the one hand it was too narrow in that the undueness test allowed for too many Type II errors - cartels that escaped punishment because they did not meet the ill-defined "unduly" standard. This high bar for even naked cartel agreements had the effect of making prosecutions more expensive and time consuming than in other jurisdictions. The general view was that "the virtual per se condemnation of price-fixing and marketsharing agreements ... should have been part of our law from its inception in 1889". ${ }^{11}$

\footnotetext{
${ }^{8}$ Kennish and Ross (1997).

${ }^{9}$ Chandler and Jackson (2000).

${ }^{10}$ An earlier version of some of the themes developed in Kennish and Ross (1997) can be found in Ross (1991). See also Warner and Trebilcock (1993).

${ }^{11}$ Stanbury and Reschenthaler (1981).
} 
On the other hand, the law was overly broad in the sense that many potentially pro-competitive and efficient form of cooperation between competitors - strategic alliances and joint ventures for example - could be caught up in criminal proceedings wholly unsuited to evaluating the economic merits of the agreement. ${ }^{12}$

The 2010 amendments took care of the Type II error directly. Naked cartels became per se illegal. In response to the concerns over potential Type I error and the discouragement of legitimate cooperation, an alternative civil review channel was opened -- in a new section (s.90.1) -- for the consideration of agreements between competitors that are not naked cartels. These could be agreements that might harm competition but that can also generate significant benefits in terms of efficiency, innovation or the introduction of new products or services. ${ }^{13}$ The design here treats such agreements much like mergers, including by having contested matters heard before the Competition Tribunal. The Bureau issued "Competitor Collaboration Guidelines" in December 2009. The Guidelines clearly recognized the value of many types of collaborations between firms that might, in other contexts, be competitors.

\section{On Overcharges and Fines}

Antitrust authorities around the world use fines to discourage the formation of cartels and to destabilize existing cartels. Fines against cartels are usually higher than those imposed against other infringements of competition laws, reflecting the consensus that price-fixing and market allocation are the most serious antitrust offenses.

The economic theory of deterrence of cartels, like other criminal activities, relies on the theory originally developed by Becker (1968). A firm is deterred from participating in a cartel if the expected net incremental profit of doing so is negative, the expected benefit coming from the cartel overcharge and the expected cost being equal to the probability of being discovered and convicted times the fine plus other penalties (including the loss of reputation, negative financial market reactions, costs and penalties from private litigation and class action). ${ }^{14}$

\footnotetext{
12 See Kennish and Ross (1997)

${ }^{13}$ Formally, the revised section 45 included a new subsection (4) that provides that the prohibitions in the section do not apply to agreements that are ancillary to, and reasonably necessary for the success of a larger agreement that itself would not violate section 45 .

${ }^{14}$ See the econometric event studies of Bosch and Eckard (1991), Thompson and Kaserman (2001), Günster and van Dijk (2016), Aguzzoni et al. (2013), and the analysis of interviews and surveys by Hüschelrath et al. (2011).
} 
The average amount of fines imposed on cartel participants has increased substantially, reaching record amounts in Canada, Europe and the U.S. over the last decade. By imposing such fines, antitrust authorities hope to achieve better deterrence, both specific deterrence by sanctioning convicted cartel participants and general deterrence by discouraging other potential violators from initiating or continuing to take part in cartels (International Competition Network 2008).

An important input into the determination of fines is the overcharge that a cartel is able to impose. A considerable literature documents the extent to which cartels have been able to raise prices. Prominent in this field is the work of John Connor. ${ }^{15}$ Estimates by Connor and others indicate that for many large detected and punished cartels studied, the excess profits earned during the collusive period exceed the total of all fines and private damage awards. ${ }^{16}$ This suggests an under-deterrence bias in the law and enforcement policies.

This literature is not without its controversies, however. Boyer and Kotchoni (2015) (BK) perform an econometric meta-analysis of the Connor database of 1119 cartels over time and regions to correct for likely biases in some cartel overcharges. BK show that raw estimates of cartel overcharge may be misleading. The differences between raw estimates and bias-corrected estimates are striking. ${ }^{17}$ For domestic cartels, the raw overcharge estimates are respectively $35 \%$ (pre-1973) and 33\% (post-1973) while the bias-corrected values are 13\% and 13\%, respectively. For international cartels, the raw overcharge estimates are 89\% (pre-1973) and 44\% (post-1973) while the corresponding bias-corrected values are $15 \%$ and $19 \% .{ }^{18}$ While BK point to biases and suggest the Connor's estimates of overcharges are too high, the simple observation of cartels would seem to provide support for his suggestion that cartel profits exceed penalties. The statement that penalties are too low is contested by Allain et al. (2011) and Allain et al. (2015) who claim that -- considering cartel dynamics, which play a major role in determining whether fines are a deterrent or not -- fines imposed by the European Commission in recent years meet

\footnotetext{
${ }^{15}$ For example, Connor (2007) and the updated online edition of Connor (2014).

16 The title of one of Connor's recent papers says it all: Connor and Lande (2012), "Cartels as Rational Business Strategy: Crime Pays".

17 The data used in the Connor database are estimates obtained from different methodologies, sources and contexts rather than from direct observations. Therefore, these data are subject to model error, estimation error, endogeneity bias, and publication bias.

${ }^{18}$ Overall, the means and medians of bias-corrected overcharge estimates suggest a somewhat more homogenous behaviour of cartels across periods and regions than the means and medians raw estimates.
} 
the deterrence objective in a significant number of cases. Moreover, a proper modeling of any crime deterrence requires a mixed strategy game framework, and under such a framework efficient deterrence will never completely eradicate crime. ${ }^{19}$

\section{The emergence of economic screening to discover cartels}

An emerging area of competition policy enforcement involves the use of screening techniques to uncover cartels. Among economists contributing to this area is Joseph Harrington (e.g. Harrington 2008a). Harrington develops a set of collusive markers, which are indicators or patterns of key variables that are expected to distinguish collusion from competition.

While there is no substantial and formal cartel screening program in Canada, the idea that competitive pricing and cartel pricing patterns will differ has come up in at least one collusion case. In this case, the idea helped date the conspiracy. The case involved gasoline retailing in Québec, Canada. ${ }^{20}$ For some cities the volatility (standard error) of prices across retailers dropped significantly in early 2001 and remained low and stable afterwards. In contrast, the price volatility observed in other cities increased continuously with increases in the level of price, as one would expect in a competitive market. Those results suggested the presence of price-fixing collusion starting in early 2001 in the group of cities. ${ }^{21}$ Under cross examination by Government prosecutors, one of the accused confessed that the cartel had indeed started in early 2001.

Screening data, while not in itself determinative, may in principle be most useful in ruling out cartels, for example in finding that price volatility is simply too high to be consistent with cartel price setting. In practice, to this point, however, screening data have not been used to rule out cartel conduct.

\section{Cartelization through coordinated conduct and facilitating practices}

In addition to explicit conspiracies, the Competition authorities must be aware of implicit coordination or tacit collusion. Perfect collusion can be supported as the outcome of a pricing

\footnotetext{
${ }^{19}$ Boyer et al (2000).

${ }^{20}$ To date, 39 individuals and 15 companies have been charged under section 45 of the Competition Act (making it the largest cartel criminal case in Canadian history with respect to the number of defendants), of which 33 individuals and seven companies have pleaded or were found guilty. Of the 33 individuals who have pleaded or were found guilty, six have been sentenced to terms of imprisonment totalling 54 months.

${ }^{21}$ One of the authors (Boyer) was an expert for the Commissioner of Competition in this matter.
} 
supergame under the right conditions. To achieve maximum cartel profits, firms need to coordinate on and enforce the desired outcome through detection and punishment and possibly payment transfers between participants. More generally, cartel member firms seek self-enforcing incentives. This principle holds both for explicit collusion (cartels) and tacit collusion (coordinated conduct).

Over the last few decades an extensive literature on "facilitating practices" has developed. These are practices that fall short of explicit collusion but that may help tacit colluders find their way to higher prices and profits by solving the three cartel problems identified by Stigler (1964): (i) coming to an agreement; (ii) detecting defections from the agreement; and (iii) punishing defection. Cartel members do this by improving the information colluding firms have about each other and the market and by altering their incentives to compete aggressively. Facilitating practices, as the name suggests, aid in achieving these aims.

As with the literature on cartel creation and stability cited earlier, research on facilitating practices has had relatively little impact on cartel prosecutions because (as we noted above) cartel cases tend to be so fact-based. Economic thinking has, however, had a significant effect on how we look at oligopolies and tacit collusion with implications for merger and abuse of dominance cases. For example, in a recent Canadian merger case, resolved by a consent agreement, the Bureau expressed concern that the transaction as first proposed would have facilitated the coordination of prices by, for example, improving the flow of information between competitors. $^{22}$ It is likely that following this important consent agreement, based in part on the increased likelihood of coordinated conduct, will give rise to a demand for similar economic analyses in future cases.

\section{Leniency and competition compliance programs.}

In the last few decades, leniency programs have proliferated in many jurisdictions where competition authorities are eager to dismantle cartels by encouraging self-reporting and cooperation from cartel participants. Even in 2008 more than 40 jurisdictions around the world had active leniency programs (O’Brien 2008 and Harrington 2008b). The popularity of these

\footnotetext{
${ }^{22}$ The 2015 case involved the proposed acquisition by Parkland Fuel Corporation (Parkland) of substantially all of the assets of Pioneer Energy LP (Pioneer) in Manitoba and Ontario. One of the authors (Boyer) served as an expert for the Commissioner in this matter.
} 
programs has increased since. The first major leniency program was introduced in the United States in 1978 but it was only with a revised program introduced in 1993 that leniency applications took off in the U.S. The U.S. program was so successful that within a short period of time many other jurisdictions had introduced leniency policies modelled on the revised American model. Canada introduced its own leniency policy in $2000 .^{23}$

These various leniency programs have the common goal of deterring antitrust violations and detecting cartel offences by using the pledge of less severe sanctions. Cartel participants are allowed to turn themselves in and cooperate with authorities in order to receive full immunity from prosecution or reductions in fines. Competition authorities in Australia, Canada, the EU and the US are increasingly bringing cartel members to justice with the cooperation of insiders.

The importance of leniency programs cannot be overstated. The programs have become a key element in the fight against hard-core cartels. ${ }^{24}$ The fraction of cases uncovered through leniency programs makes these programs the most important instrument in competition authorities' toolbox when it comes to dealing with suspected cartels. There is now a considerable economic literature on how leniency programs can affect cartel stability. ${ }^{25}$

Some research has found that leniency policies could actually support collusive activity under certain circumstances, for example if they lower the expected level of fines too much and for too many of the cartel participants. ${ }^{26}$ Leniency program provisions, found in some countries, that deny leniency to cartel instigators may also serve to make the instigator's commitment to the cartel more credible to other firms, and thereby enhance cartel stability. ${ }^{27}$

A "compliance first" orientation of many competition authorities, in addition to the rising levels of fines and highly publicized cartel cases have probably contributed to the proliferation of corporate compliance programs through which employees are educated about their

\footnotetext{
${ }^{23}$ Competition Bureau (2010), represents the current version of the Canadian leniency policy.

${ }^{24}$ Storli (2014).

${ }^{25}$ Spagnolo (2008) is an excellent survey. Other important papers include Spagnolo (2004), Motta and Polo (2003) and Harrington (2008b).

${ }^{26}$ Of course, if fines were set too high, then this effect can bring us closer to optimal deterrence. See Allain et al. (2015).

${ }^{27}$ For example, see Chen et al (2015).
} 
responsibilities under the existing competition regime. A consensus has emerged on what an effective compliance program should include (Competition Bureau 2015). ${ }^{28}$

\section{Looking ahead}

Given that the economic theory of collusion is relatively settled we might not expect dramatic changes in modern approaches to cartel law in the near future. We expect these cases to continue to be largely fact-driven, propelled by evidence of actual meetings, communications and agreements. That said, there are areas in which we may see cartel policy change. We mention four briefly. First, in jurisdictions such as Canada and the U.S. (and increasingly others) we see private enforcement (for the recovery of damages) of laws against price-fixing. Finding the right balance between private and public enforcement - and the right way for private and public enforcers to cooperate - is a work in progress. ${ }^{29}$ Second, we expect that leniency programs will continue to evolve, as countries tinker with rules regarding the level of leniency to be offered, how broadly it is to be offered, and when it can be denied. Third, as successful as leniency policies have been, competition authorities are searching for other ways to detect cartels including screening. Screening techniques are relatively new and are employed by only a small number of competition agencies - but that could change as we learn more about which markers matter and how well they uncover new cases of collusion. Finally the debate about the appropriate level of punishments will continue. One aspect of this relates to the level of fines are they too low or too high? But there is also the question of the mix between punishing firms and individuals, and for the latter the use of prison sentences and other penalties.

\footnotetext{
${ }^{28}$ The Canadian Competition Bureau articulates the benefits to a firm of a compliance program this way: “... first, it signals an entity's seriousness in tackling and addressing the legal obligations and ethical considerations facing businesses today; second, it reduces costs of compliance by helping to clarify, for business managers and officers, the boundaries of permissible conduct as well as situations that could put their business at risk of violating the Acts; and third, should there be any violations of the Acts, it provides a possibility for the business to mitigate the cost of non-compliance."

${ }^{29}$ The private cartel enforcement regime in Canada - particularly as it relates to class actions - has been evolving in important ways recently, for example, with key court decisions clarifying which purchasers have the right to sue for damages.
} 


\section{Single Firm Conduct}

\section{Introduction: the issue}

Legal restrictions on the strategies taken by single firms are perhaps the most contentious area of competition policy. As in other areas, the role of economics has changed over 50 years from being almost non-existent to the point where it is completely integrated into virtually every case. The law draws on modern industrial organization in a way that seems completely natural now, but was impossible around 1970 because the tools of analysis had not yet been developed.

In undergraduate textbooks, the market strategies of a firm are simple: the firm sets a price for each product. The firm has no incentive to impose conditions on the buyers of its product. In reality, the set of firm strategies is much more complex. If the buyer is an intermediary such as a retailer, the seller may impose restrictions on the price at which the buyer may resell the product, the customers to whom it may be resold or the geographic areas within which the product may be sold. The seller may agree to contingent prices in the future, prices that depend upon the prices that the buyer is able to obtain from other sellers, and so on.

The following are the main single firm strategies that are restricted by competition policy: Resale price maintenance: a ceiling or (more often) a floor imposed by a supplier on the price at which a retailer may sell the supplier's product; Territorial restrictions: a limit on the territories in which a retailer or distributor may resell the supplier's product; Restrictions against reselling on the Internet: imposed frequently by luxury good suppliers; Exclusivity Restrictions: a restriction that the buyer not purchase from any rival supplier, or that the supplier not sell to any other buyer; Tying (requirements tying): a constraint that the buyer of product $\mathrm{A}$ from a supplier purchase all of its requirements of a product B from the same supplier; Bundling: a restriction that products A and B be purchased as a bundle; Loyalty Discounts or rebates: price discounts based on the share of the buyer's total requirements purchased from the supplier; Meeting competition clauses and MFN clauses: the supplier agrees to meet any price offered to the buyer by another supplier in the future; alternatively, the best price that the supplier offers another buyer; Vertical MFN clauses: a restriction that the retailer not sell a rival's product for a lower price than the supplier's product; Right of first refusal (or "meet-or-release"): the right of the supplier to meet any price that a buyer is offered in the future; Predatory pricing: pricing below cost for the 
purpose of inducing exit, or preventing the entry of a potential entrant, recouping lost profits through higher prices once the exit has occurred or threat of entry has disappeared. ${ }^{30}$

As a matter of law, the Canadian Competition Act governs intervention in this area mainly through three sections: section 79, on Abuse of Dominance, section 77 on exclusive dealing, tied selling and market restriction, and section 76 on resale price maintenance. ${ }^{31}$ Section 79 is a fairly general provision against potentially abusive strategies, allowing a remedy to be imposed if a dominant firm engages in the practice that is likely to substantially lessen or prevent competition. Section 77 applies when the listed actions (not necessarily employed by dominant firms) lessen competition "substantially". Section 76 covers resale price maintenance that has "an adverse effect on competition."

We offer some general remarks about the integration of economic thinking into law and policy in this area, and then turn to three examples of single-firm strategies in which economics has been particularly influential.

\section{The Integration of Economics into the Law on Single Firm Conduct}

As in all areas of competition policy, the economic basis for intervention is driven by evidence of the suppression of competition reflecting either exclusion (as in the example of the last paragraph) or higher prices. Yet a contractual restraint that is anticompetitive in either of these ways under some circumstances can be a pro-competitive, efficient restraint in other circumstances, to the benefit of both the contracting parties and agents outside the contract. It is fair to say that competition policy has reached (or nearly reached) the point where a single-firm strategy being challenged in a court proceeding involves developing hypotheses as to the incentive for the contract, and testing these theories against evidence adduced in an adversarial system - the process being guided by economic reasoning.

This, of course, is the application to competition policy of the basic scientific method. The application of the scientific method is one of the key components of economic thinking (and thinking in other social sciences). One implication of the scientific approach is that intervention

\footnotetext{
${ }^{30}$ We set aside economic theories of "above-cost" predatory pricing, as not having been strongly influential in the law. In our view, distinguishing predatory pricing from low, competitive pricing is challenging enough with the necessary condition that prices fall below marginal cost.

${ }^{31}$ Other relevant sections include section 75 on refusal to deal and section 80 on delivered pricing.
} 
in a market requires a theory of harm, i.e., a theory of market failure. We discuss below three additional aspects of economic thinking that have been increasingly influential: consequentialism, welfarism and the game-theoretic approach to evaluating the impact of restrictions on firm strategies.

Economics is fundamentally consequentialist. Economists would design the law to prohibit a particular contract in a set of circumstances if the impact of doing so - the change in the market outcome -- were beneficial, according to whatever criterion is adopted. This is such a basic point that it is hard for an economist to imagine another way of thinking. But the law on vertical restraints has not always been so designed. Early cases on vertical restraints were influenced, for example, by an old principle in Anglo-American property law against restraints on alienation: that once an individual gives up possession of a piece of property, the individual no longer has the legal right to dictate what can and cannot be done with the property. ${ }^{32}$ The rule against restraints on alienation constrained contracts on a distinctly non-consequentialist basis.

This type of "pre-economics" thinking is still lurking in the shadows of competition policy. The European Guidelines on Vertical Restraints from 2010, for example, include the following:

"The Internet is a powerful tool to reach more and different customers than will be reached when only more traditional sales methods are used ... In principle, every distributor must be allowed to use the internet to sell products." 33

This statement sounds plausible, but is in fact not based at all on the consequences of restricting prohibitions of distribution over the internet. The statement, in a set of guidelines which economists had a hand in writing, is no more consequentialist than the principle against restraints on alienation. The law on single firm strategies (and elsewhere) is consistent with economics only where the ruling in each case or each class of cases is evaluated in terms of the impact that it has on the market, not in terms of its adherence to a legal principle. ${ }^{34}$

\footnotetext{
${ }^{32}$ The common law rule against restraints on alienation was the principle basis for the most important early case on resale price maintenance, Dr. Miles Medical Co. v. John D. Park \& Sons Co., 220 U.S. 373, 409 (1911). Rogers (1996) notes that the rule against restraints on alienation was "soundly discredited as a viable antitrust goal" by the U.S. Supreme Court in the important case Continental T.V. vs GTE Sylvania 433 U.S. 36,53 n.21 (1977).

${ }^{33}$ European Commission (2010) II 52.

${ }^{34}$ Note that consequentialism does not rule out per se rules, that may not be free of error in each case but which provide valuable legal guidance to firms. Per se rules, such as the rule against coordination on prices by competing firms, will have errors in some cases (errors of Type I) but the value of the simple rule as guidance may offset the
} 
The second influential dimension of economic thinking in this area is welfarism. ${ }^{35}$ This is the criterion that once we adopt consequentialism as an axiom the impact of a law should be assessed according to its impact on the welfare of market participants. The criterion for assessment may be consumer surplus, or total surplus, or it may be the vector of utilities and profits gained by market participants ranked by the Pareto criterion. But the criterion is not protecting "the intensity of competition in the market" or preserving low concentration, or protecting small firms against large firms, and so on. The error in thinking of a competitive market structure as an end in itself rather than a means to greater welfare often arises in competition law (“error" we arrogantly define as inconsistent with economic principles).

In the area of the law related to exclusivity restrictions, for example, rejection of a strategy simply on the grounds that it makes a dominant firm more dominant may be consequentialist, but it is not welfarist. "Big is bad" is a pre-economics way of thinking. As we discuss in the next subsection, there may be solid reasons to object to exclusivity contracts as anticompetitive, but these require careful economic development in a case.

The third way in which economic thinking has increasingly influenced antitrust law in the area of single firm strategies is involving the kind of structured thinking that comes with the application of game theory, contract theory and industrial organization theory in general. An evaluation or prediction of the effects of the law in the area of the single firm strategies must recognize the sequential nature of the strategic interaction of the players where contracts are involved: first, the law places a restriction on the set of contracts that firms must enter into; second, the contracts are chosen and entered into voluntarily; third, market participants act rationally given the restrictions imposed by the contracts that they have entered. This hierarchical game must of course be solved via backwards induction. Once more, this is now such a natural way of thinking for an industrial organization economist that it is hard to believe that the underlying game-theoretic foundation, sub-game perfection, entered the mainstream toolbox of our field only in the 1970's,

cost of errors. We note also that simple legal rules that appear to be non-consequentialist in a particular case may nonetheless be efficient in the long run sense of providing clear rules to market participants

35 Kaplow and Shavell (2001) is the clearest treatment of welfarism in economic policy. 
especially with Dixit (1980). Contract theory, a subset of game theory, has been particularly influential. ${ }^{36}$

Several kinds of departures from this sequential or game-theoretic way of thinking arise in competition policy arguments. The first is simply the failure to organize thinking around the sequential structure. Resale price maintenance was traditionally considered anticompetitive, for example, because ceteris paribus it appears to raise retail prices. This argument is wrong because a supplier upstream benefits from lower retail prices, ceteris paribus, once its wholesale price is fixed. An evaluation of resale price maintenance in a particular case must include a theory in which the supplier gains in some dimension that compensates the supplier for the higher prices. In other words, to show a vertical restraint is anticompetitive, it is not enough to argue that an individual would be better off if unrestrained. Virtually any individual in any contract would be better off with the removal of a contractual constraint, if nothing else changed.

The second, and related, error in deviating from the structure provided by game theory is the failure to recognize the (admittedly confusing) double-negative nature of policy in the area of vertical restraints. Most of the contracts listed above prohibit particular actions on the part of downstream agents. The policy question is therefore whether to prohibit the prohibition inherent in the restraints. ${ }^{37}$ To take an example, a recent Canadian case, Visa, involved a vertical restraint in the market for credit card services, the prohibition of "no-surcharge rules" by credit card companies. The policy question at issue in this case was not whether to allow merchants to surcharge purchases with particular credit cards. The issue was whether to prohibit the prohibition by credit card companies of merchant surcharging. Failure to identify the right policy question can lead to substantial confusion.

A third departure from the game-theoretic or contract-theoretic approach is the failure to recognize the undeniable fact that contracts are voluntary. For example, in a 1991 Canadian case on exclusionary restrictions, the government's economic expert argued that "The dangers from contracting arise when one side of the market has the power to impose contract terms on the other ... If one contracting party is a monopolist ... it can preserve its market power by

\footnotetext{
${ }^{36}$ Rey and Tirole (1986) and Mathewson and Winter (1984) introduced the application of the principal-agent perspective of Shavell (1979) and Holmstrom (1979) to the theory of vertical restraints.

${ }^{37}$ For example, resale price maintenance is a prohibition against low prices.
} 
insisting that its customers (or suppliers) sign long-term contracts." ${ }^{38}$ A coherent evaluation of the law on any contract must recognize (as the early Chicago School did) that, setting aside imperfect information, a restrictive contract is Pareto optimal among the parties signing the contract. The contracts may make the buyers collectively worse off because of contracting externalities, but a contractual restriction cannot be labelled an exercise of market power because buyers would prefer to be unrestricted.

Bringing together the three dimensions of economic thinking leads us to a conceptually simple answer to the basic questions in this area: Why should competition policy restrict any of these strategies? Why not settle for laissez-faire, leaving buyers and sellers free to enter whichever contracts they choose? After all, parties will enter contracts only if they are better off as a result. The answer is that contracts may impose externalities on parties outside the contract. This perspective is particularly valuable in understanding exclusivity restrictions, but can be understood more broadly as a unifying theme of why vertical restraints can be anticompetitive.

A full development of the influence of economics in this area would illustrate the integration of these dimensions of economic thinking into the law on each of contracts listed above. This is well beyond the scope of this review. Instead, we outline a single influential economic idea from each of three areas: resale price maintenance, because it is historically by far the most important vertical restraint in terms of the law and in terms of the impact of economics; exclusivity restraints, because these restraints nicely illustrate the role of economic theory and are featured in several prominent Canadian cases; and predatory pricing as an example of a non-contractual strategy.

\section{Examples of Specific Practices}

\section{Resale Price Maintenance}

Resale price maintenance ${ }^{39}$ was an extraordinarily popular vertical restraint before the law prohibiting it was enacted in Canada in 1951. An estimated 20 percent of goods of all types sold through grocery stores and 60 percent sold through drugstores were subject to resale price

\footnotetext{
${ }^{38}$ Report of the Commissioner's economic expert in Laidlaw, paras 21 and 42.

${ }^{39}$ We stick to a narrow definition of resale price maintenance as a contractually imposed price floor, for the most part.
} 
maintenance in Canada. ${ }^{40}$ The popularity of imposing a price floor has long been regarded as puzzling, because other things equal an upstream supplier benefits from the greater demand that comes with a lower price.

Between 1951 and the amendment in March 2009 of the Canadian Competition Act, resale price maintenance was per se illegal as a criminal act. This was absurd from the perspective of economics. ${ }^{41}$ With the amendment, resale price maintenance became a reviewable practice under the civil section of the Act.

A more accurate indicator of how policy towards resale price maintenance changed over time in practice, however, is in the time-line of cases brought by the Canadian Competition Bureau, as reviewed in Winter (2009). The Bureau brought more than 100 resale price maintenance cases in the 1980's, dropping to 17 cases in the 1990'sClaude Morrow, a Canadian legal practitioner, traced this trend in the law on resale price maintenance to specific publications of economists writing in the field. ${ }^{42}$ The impact of economic thinking in this area was unambiguous, and recognized by practitioners.

Resale price maintenance, in the pre-economics way of thinking, is anticompetitive simply because it prevents retailers from reducing price. This begs the question of why a manufacturer would want to impose resale price maintenance: given its wholesale price a manufacturer benefits from lower retailer prices, other things equal, because retail demand curves are downward sloping. One set of answers is that resale price maintenance can facilitate collusion among upstream suppliers (Telser 1960; Julien and Rey 2007) or exclusion by an upstream supplier (Asker and Heski (2014) or collusion involving downstream retailers. ${ }^{43}$ Indeed, the argument that a manufacturer on its own would not impose a price floor on downstream retailers may have been influential in the strict laws against the vertical restraint.

\footnotetext{
${ }^{40}$ Overstreet (1983, 153 and 155).

${ }^{41}$ In the pre-2009 period, a colleague of ours, testifying in a Canadian competition case, offered a persuasive and conventional (free-riding) explanation of why a particular firm was adopting resale price maintenance. Our colleague was afterwards thanked profusely, almost tearfully, by the CEO of the defending company for absolving the CEO of a crime.

${ }^{42}$ Morrow (1990).

${ }^{43}$ Additional theories of resale price maintenance as anticompetitive include Rey and Vergé (2010) who show that in the presence of interlocking relationships between upstream suppliers and downstream distributors, resale price maintenance may reduce both upstream and downstream competition because of common-agency type effects. The superb unpublished survey by Rey (2012) offers some case examples.
} 
An examination of the vast set of resale price maintenance cases, however, finds that most do not fit the anti-competitive theories (see, for example, Ippolito 1991). The alternative theory is simply to recognize two things. First, downstream demand in most retail markets depends on just on price but on other retailer actions, such as the provision of information or simply the reduction of transactions costs such as the time spent shopping through other services, such as short cashier lines, readily available sales staff and well-organized inventory. Second, retailer's choice in the mix of price and non-price determinants of demand may be biased towards too much price competition and too little competition in the service dimension. This bias may result from free-riding problems in which consumers acquire information at one store and purchase the product at another, low-priced store (Telser 1960). Or from the recognition that each retailer chooses its strategy to attract marginal consumers both to the product and away from other retailers (Winter 1993). Marginal consumers drawn from other retailers are insensitive to timesaving relative to price (the fact that they choose to shop among retailers means that their costs of time are low). The manufacturer would like retailers to ignore consumers on the interretailer margin since these consumers do not add to total demand for the product. Retailers, in short, are biased in their sales strategy because from the perspective of maximizing total supply chain profit they compete on the "wrong margin." Among many other theories of resale price maintenance as being in the interest of a single manufacturer are Klein and Murphy (1988) and Klein (2009).

What are the policy implications of these theories (and others) of resale price maintenance by a single upstream supplier? Can we be assured that when the monopolist shifts to greater sales effort (promotion or any retailer expenditure on attracting demand) at the expense of higher prices that welfare or consumer surplus rises? We cannot. But this is the wrong question. The burden of proof in any intervention in a market lies on the side of the intervener. There is no basis for presuming the manufacturer's choice of strategy is consistently or even discernably wrong. Resale price maintenance appears most often to be an instrument for shifting the mix of price and service (sales effort, prominent displays, and transactions-cost lowering strategies) at the retail level. We do not regulate firms' choice of this strategy mix, even in the case of a 
monopoly, where the choice is implemented directly. Nor should we were the choice is implemented via incentive contracts. ${ }^{44}$

\section{Exclusivity Restrictions}

Exclusivity restrictions refer to a contract for supply in which the buyer (typically an intermediary such as a retailer) agrees to deal with only the supplier, or in which the supplier agrees to supply only the buyer. The essence of the contracts is an agreement not to deal with competitors to the other side of the contract.

The possible efficient uses of exclusivity contracts are now well established, having been developed in economics and integrated into the law. Exclusivity restrictions may be used as a response to specific investment and the resulting holdup problem. If one side of a contract, say the seller, undertakes substantial investment in the relationship before future transactions take place, the other side of the contract (the buyer) may be in a position to threaten to deal with agents outside the contract. The seller, anticipating that the buyer will renegotiate future prices to capture some of the returns (quasi-rents) from the investment, will invest with the anticipation of capturing only part of the return. This inefficiency reduces the gain from contracting, and it is to the parties' advantage to prevent the hold-up problem. Exclusivity restrictions and long-term contracts are a clear solution. ${ }^{45}$ Where the contract binds both parties to exclusivity, the relationship is referred to as quasi-vertical integration.

Firms may also use exclusivity to protect against free-riding problems (Marvel (1982)). If an insurance broker contracts with an insurance company that invests substantially in promotion and advertising, another insurance company may adopt the strategy of low-cost insurance without advertising. The broker would benefit customers, attracted by the promotion of the first insurer, by suggesting they switch to the lower cost policy. The low-cost supplier free rides on the

\footnotetext{
${ }^{44}$ As the Canadian Standing Committee on Industry, Science and Technology (SCIST) expressed it: From the consumer's perspective, vertical price maintenance results in more services, which we would regard as good, but higher prices, which we would view as bad... Prohibiting resale price maintenance under the per se rule is effectively regulating the manufacturer's decisions on how best to maximize the sale of his products. By way of an analogy, we do not prohibit by law high levels of advertising even when such advertising raises prices; for the same reason we should not prohibit vertical price maintenance under a per se rule." Canada SCIST (2002), Chapter 5.

${ }^{45}$ See, e.g., Segal and Whinston (2000) and Joskow (1987).
} 
investment in promotion by the higher-cost supplier, in this story. An exclusive agency contract clearly prevents the free-riding story. This theory clearly has some legitimate applications, but it is a theory without a tight boundary. One can count on hearing a free-riding defense of any contractual restriction that induces exclusivity among retailers. Retailers without exclusivity restrictions might sell products that were in some cases not the product for which customers were initially attracted to the retailer. The prevalence and frequent success of free-riding arguments is yet another example of the influence of economics in cases involving single-firm strategies. In a recent U.S. case before an appellate court, the issue was the legality of a vertical restriction referred to as a "no-steering restraint" - that retailers not encourage customers to switch to a competitive service to the one supplied by the upstream firm. In finding for the defendant, reversing the lower court's decision, the appellate court cited favourably the free-riding defense of the defendant, American Express. ${ }^{46}$

Where the economic thinking in this area has most evolved is in the anticompetitive uses of the contracts. Whether these contracts can even have an anticompetitive, exclusionary effect has historically been a contentious question. The "pre-economics" view of exclusivity restrictions is that the restrictions were imposed on buyers (for example), with the effect of monopolization to the detriment of buyers. The early Chicago response to this traditional view was the contracts are voluntary. If a dominant supplier has extracted the entire surplus that it can from a buyer, then it can impose a restriction such as exclusivity only if it gives the buyer something in return. ${ }^{47}$ The parties will sign the restriction only if it efficient. ${ }^{48}$

The "post-Chicago" response to this argument is that an exclusivity contract can be inefficient if it imposes externalities on parties outside the contract. The key contribution here is Agrion and Bolton (1987). Agrion and Bolton considered a model in which a potential entrant, poised to

\footnotetext{
46 U.S. v. Am. Express Co., 2016 WL 5349734 (2d Cir. Sep. 26, 2016). The free-riding defense was not the main basis for reversing the lower court's decision, but was cited positively and may have been influential (although the appellate court in principle does not re-assess factual evidence).

${ }^{47}$ If the restraint is being used to extract additional surplus from the buyer then it is essentially a pricediscrimination device. Price discrimination is not predictably surplus decreasing and therefore not problematic.

${ }^{48}$ Bork (1978) states "The truth appears to be that there has never been a case in which exclusive dealing or requirements contracts were shown to injure competition. A seller who wants exclusivity must give the buyer something for it. If he gives a lower price, the reason must be that the seller expected the arrangement to create efficiencies that justify the lower price."
} 
enter the market, has uncertain costs. Prior to the realization of these costs, an incumbent in the market can sign a long-term, exclusive contract with the buyer in the market (a single buyer, for simplicity). The contract contains a stipulated damage, $d$, that the buyer must pay to leave the contract. If the entrant's realized costs are low enough, it can enter the market - but to do so it must offer a price low enough to induce the buyer to exit the long-term contract with the incumbent. The higher the damage, $\mathrm{d}$, and the lower the entrant's price must be. The initial contract thus extracts a transfer from the entrant. The contract is anticompetitive, or inefficient, in the sense that the profit-maximizing contract (the value d) is designed such that even an efficient potential entrant, with a realized cost less than the incumbent's cost, may be deterred from entering the market.

The externality imposed on the entrant is but one of many externalities on parties external to a contract that may render a contract anticompetitive. A second externality is across buyers: a buyer may be induced into signing a long-term, exclusive contract with only a small inducement (bribe) because the buyer does not incorporate the impact of the contract on all other buyers. This impact is to render entry more difficult, if the entrant needs substantial buyers to cover fixed costs, and the incumbent signs up most or all of the buyers in the market. This second externality, as a basis for anticompetitive exclusionary contracts was introduced by Agrion and Bolton, and explored in by Rasmussen et al (1991), and Segal and Whinstone (2000). A Canadian case, Laidlaw nicely illustrates this externality as a basis for exclusionary contracts. ${ }^{49}$ A third externality that may induce anticompetitive exclusionary contracts operates along the supply chain, rather than horizontally across buyers (Jing and Winter 2013). Suppose that an incumbent anticipates negotiating with an upstream supplier, which has market power. The incumbent can negotiate long-term exclusive contracts with buyers further downstream. These contracts render participation in the market less profitable for entrants at the same stage as the

\footnotetext{
${ }^{49}$ In Laidlaw, Entrants into local commercial waste disposal markets required sufficient numbers of available buyers because of the substantial fixed (though not sunk) costs of a single garbage truck. .Recovering these costs is rendered more difficult by the economies of density in the market, that is, the costs of having to service a given number of available buyers spread out in the community. A single truck required a volume of sales in the order of $10 \%$ of the local market in several of these communities. With the staggering of long-term contracts by Laidlaw, the time to accumulate a sufficient number of buyers represented a significant entry cost. The externalities across buyers in accepting the contracts - and in being diligent in keeping track of the termination date of the contract so that sufficient notice of termination could be given - were clearly operative in the market. Buyers entered and renewed long-term contracts in spite of the potential collective benefits of facilitating entry by insisting on short-term (month-to-month) contracts.
} 
rival, or the incumbents' rivals, because fewer customers are available to these rivals to cover their fixed costs. This reduction in profitability lowers the rivals' willingness to pay for inputs provided by the upstream supplier - making it easier for the incumbent to negotiate a lower price.

We mention a final externality that can induce anticompetitive exclusionary contracts, although there are more. In the face of potential entry, an incumbent can induce a fixed number of upstream input suppliers to sell to it exclusively, thus protecting its monopoly position. It must solve the obvious "hold-out problem" that some input suppliers would be tempted to supply the entrant instead, but with enough product differentiation, this is possible.

Jing and Winter argue that the Canadian case, Nielsen, illustrates all four of these potential incentives for exclusionary contracts. ${ }^{50}$ The Competition Tribunal agreed with the Commissioner that the contracts in this case were anticompetitive, striking down the essential exclusivity clauses in the contracts.

\section{Predatory Pricing}

Predatory pricing represents an area in which economic thought has had a large and positive impact on the law. Until the amendments to the Competition Act in 2009, the predatory pricing section of the Act proscribed as a criminal act that practice of selling a product at "unreasonably low prices" with the "effect or tendency of substantially lessening competition or eliminating a competitor, or designed to have such an effect" (emphasis added). Thus Hoffman-LaRoche was convicted of predatory pricing for giving away Valium (diazepam) at a zero price to hospitals, where it was provided to patients. ${ }^{51}$ The law was inconsistent with economics in that eliminating a competitor cannot be considered an anticompetitive act; eliminating a rival is neither necessary nor sufficient for pricing to be anticompetitive. Competition policy is about protecting competition, not protecting competitors. As a matter of economics, predatory pricing requires more than prices below marginal cost. It also requires the prospect of recoupment, of profits once low-price competitors are eliminated. In Hoffman-LaRoche, the recoupment test failed because subsequent to the episode of low pricing more than a dozen generic producers of the drug

\footnotetext{
${ }^{50}$ Canada (Director of Investigation and Research) v. D \& B Companies of Canada Ltd. (1995), 64 C.P.R. (3d) 216 (Comp. Trib.) ("Nielsen")

${ }^{51}$ R. v. Hoffman-LaRoche Ltd. (1980) 28 O.R. (2d) 164 (J.C.J.), aff’d (1981), 33 O.R.(2d) 694 (C.A>
} 
(predictably) entered the market. The practice by Hoffman-LaRoche of giving away the drug at hospitals is easily explained by consumer switching costs; in markets with switching costs, early sellers of a product will engage in below-marginal-cost pricing as a means of investing in market share. $^{52}$

Air Canada, ${ }^{53}$ another Canadian case, illustrates the practical difficulties in relying on price-cost tests, even setting aside any conceptual difficulties with the tests. In this case, the accounting costs of Air Canada were separated into 43 categories, and each category was assessed as to whether it was an avoidable cost (roughly, an opportunity cost) on the basis of a set of factors, such as whether the particular cost was offset by net revenue from passengers taking connecting flights. The two sides agreed that 17 of the categories were avoidable and disagreed on 26 categories; the Tribunal found that 19 of the 26 disputed categories were avoidable and 7 were not. ${ }^{54}$ The case was dropped before the Tribunal had decided whether Air Canada's pricing practices substantially lessened competition (in what was to be Phase II of the hearing) when Air Canada - the alleged predator in the case - declared bankruptcy.

\section{Merger Policy}

Provisions to protect Canadians from anticompetitive mergers have been part of Canadian competition law since the passage of the first Combines Investigation Act in 1910. Canadian merger law enforcement, however, was quiet until the passage of the Competition Act in $1986 .{ }^{55}$ Very few merger cases were brought by the government between 1910 and 1986, for two main reasons. First, for much of this time there was not a properly designed and resourced enforcement agency - indeed there was no agency at all until 1923. ${ }^{56}$ More importantly, until 1986 merger law was criminal law in Canada. That criminal law is wholly inappropriate for the review of potentially anticompetitive mergers seems obvious now, and is widely recognized. The use of criminal sanctions to control conduct about which the effects are very uncertain

\footnotetext{
${ }^{52}$ Consumers (patients) who were given Valium in hospitals were presumably more likely to choose Valium in the future. The strategy of giving away Valium for free in hospitals was therefore an investment by Hoffman-LaRoche in future market share from these customers. See Klemperer (1987) for a discussion of the implications of consumer switching costs.

${ }^{53}$ Commissioner of Competition v. Air Canada (2003), 26 C.P.R. (4 $\left.{ }^{\text {th }}\right) 476$ (Comp.Trib.)

${ }^{54}$ See Csorgo (2009).

55 See, e.g., Ross (1998).

${ }^{56}$ Amendments that created an agency in 1919 were subsequently ruled unconstitutional.
} 
(making it hard for actors to know if they are breaking the law) and the high standard of proof (beyond a reasonable doubt) made judges understandably reluctant to convict. Key precedents in the Canadian Breweries (1960), B.C. Sugar (1960) and K.C. Irving (1976) cases made it extremely difficult for the Crown to win cases. ${ }^{57}$

The new civil merger provisions may have been the most important elements introduced in the 1986 Competition Act. To an economist the changes are particularly striking - Canada moved from a regime in which its merger law was devoid of economic foundations and something of an embarrassment, to a law that incorporated modern economic thinking about merger policy. Not only did it bring Canada to the standards of leading competition policy jurisdictions, it introduced novel elements that made Canada a trailblazer in the integration of economic foundations into merger policy.

\section{Evolution of economic thought regarding mergers}

In the first half of the twentieth century competition policy lacked solid economic foundations. As part of what has sometimes been called the "inhospitability tradition", "big was bad" and mergers that led to large firms, particularly firms larger than their rivals, were to be blocked in jurisdictions, like the U.S., where merger law was enforceable. ${ }^{58}$

Changes in economists' views of antitrust, particularly the recognition of the need for a "theory of harm" prior to any intervention, eventually started to take hold on policy makers and enforcers in the merger area. The Merger Enforcement Guidelines issued by the U.S. Department of Justice in 1968 might seem simplistic compared to today's Guidelines (in the U.S., Canada and elsewhere) but the Guidelines set a new standard for review transparency and respect for economics. The 1968 Guidelines were particularly tough on mergers, with very low "likely challenge" market share thresholds. Later, the theoretical backbone of the 1968 guidelines, the structure-conduct-performance paradigm, was replaced by more modern industrial organization

\footnotetext{
${ }^{57}$ R. v. Canadian Breweries Ltd (1960), 34 C.P.R. 179 (H.C.J.); R. v. British Columbia Sugar Refining Co. Ltd. and B.C. Sugar Refinery Ltd. (1960), 38 C.P.R. 177 (Man. Q.B.); and R. v. K.C. Irving Ltd. and Three Other

Corporations (1976), 32 C.C.C. 1, 12 N.R. 458 (S.C.C.). For example, in the B.C. Sugar case the Court ruled that, to be blocked, a merger must result in a virtual elimination of competition.

58 As noted above, despite a similar inhospitability in Canada, the criminal nature of Canadian merger law prior to 1986 made enforcement very difficult.
} 
theory and subsequent versions of the U.S. Guidelines would incorporate new learning on competition, establish higher thresholds and introduce new techniques for merger review.

\section{Merger Provisions in the 1986 Competition Act}

The merger provisions introduced into Canadian law in 1986 reflected much of the learning from the previous Canadian law, from the U.S. experience and from evolving ideas in industrial organization economics. We highlight a few key examples here.

First, mergers became reviewable on a civil or administrative basis by a newly created expert Competition Tribunal. ${ }^{59}$ These changes reflected the need for both a civil (not criminal) legal basis, as well as specialized panels able to understand and apply the economic evidence brought by both sides of a merger case.

Second, consistent with the overall purpose of the Act, the merger provisions clearly support the protection of competition for its instrumental value in creating economic efficiency. The focus is not on blocking large mergers per se, but on stopping mergers that would prevent or lessen competition substantially. Importantly, Section 92(2) explicitly rejects the earlier structural approach to mergers, stating that the Tribunal may not conclude that a merger prevents or lessens competition substantially "solely on the basis of evidence of concentration or market share." Section 93 of the Act lists a number of factors to be considered that would allow the Tribunal to focus on the competitive effects of the transaction and not just the size of the parties. For example, it instructs the Tribunal that it may consider such factors as: (i) the role of foreign competition in domestic markets; (ii) whether the acquired firm may have been about to fail and exit the market in any case; (iii) the degree to which good substitutes exist for the products or services provided by the merging parties; (iv) barriers to entry; (v) the extent to which effective competition remains; (vi) the extent to which the merger will remove a vigorous or effective competitor; and (vii) the nature and extent of change and innovation in the market. These are all factors that economic theory would argue are relevant to an evaluation of the competitive effects of a transaction. While the structure-conduct-performance paradigm did recognize roles for many

\footnotetext{
${ }^{59}$ The Competition Tribunal is made up of a combination of certain designated judges from the Federal Court of Canada and lay members who are to be appointed based on their expertise in business, economics and related fields.
} 
of these factors, the newer thinking added emphasis on feedback effects from conduct and performance to structure and on the role of potential competition.

Third, and most dramatically, the merger provisions introduced an explicit efficiency exemption for mergers that prevent or lessen competition if the merger "has brought about or is likely to bring about gains in efficiency that will be greater than, and will offset, the effects of any prevention or lessening of competition that will result or is likely to result from the merger or proposed merger and that the gains in efficiency would not likely be attained if the order were made." (S. 96(1)). ${ }^{60}$ This provision put Canada in the vanguard of jurisdictions looking for ways to integrate efficiency considerations into the review of potentially anticompetitive mergers and it has led to probably the most interesting contested merger cases.

Responding to pressure from economists, since at least the 1970 s a number of other active competition policy jurisdictions have been expanding the role for efficiencies to enter the antitrust law of not just mergers but other agreements between competitors, as well as vertical restraints. ${ }^{61}$ This evolution in thinking is captured in changes to the U.S. Horizontal Merger Guidelines. But no jurisdiction has put as much weight on efficiencies as Canada has. Only in Canada has a merger that was predicted to raise prices by 10 percent was allowed on the basis of efficiencies.

Efficiencies should, and generally will, only come into play in a merger case if there are concerns that the transaction will harm competition. We then need some way to combine the bad effects on competition with the good effects of the efficiencies in order to produce a decision rule. Competition economists have come to recognize two main approaches to the question of what welfare standard should be used to trade off efficiencies against harms to competition. ${ }^{62}$ In what is essentially the standard in the United States and many other countries, the focus is on the effect on consumers. Under the "price standard" or, more generally, a "consumer welfare standard" mergers are to be prohibited if consumers will be harmed. In this case, efficiencies

\footnotetext{
${ }^{60}$ An influential report on competition policy prepared by the Economic Council of Canada (1969) had stressed the need for Canadian firms to be allowed to reach efficient scale, to lower unit costs and become more globally competitive.

${ }^{61}$ See, for example, Kolasky and Dick (2003).

${ }^{62}$ On the different welfare standards with a discussion about the Canadian experience, see Ross and Winter (2005).
} 
will need to be large enough that the downward pressure they exert on prices is at least as great as the upward pressure created by any additional market power created by the merger. ${ }^{63}$

By contrast, the Canadian model created by the 1986 law is closer to a "total welfare standard" under which the surpluses received by consumers and the merging firms are summed and a merger is allowed if total surplus increases. ${ }^{64}$ Under the Canadian standard, consumers can be harmed by the loss of competition attributable to the merger and yet the merger may be allowed if the gains in efficiency "will be greater than, and will offset" the effects flowing from the loss of competition. The Act does not explain how to measure the effects on competition or whether "greater than, and will offset" refers to simply adding up harms and efficiencies. However, most observers at first read this as a total welfare standard: the harm to competition would be measured by the deadweight losses attributable to the reduced competition post-merger and the "greater than and offset" test just required comparing that harm to the magnitude of cognizable efficiencies. ${ }^{65}$ If the efficiencies are greater, the merger is to be allowed. Clearly these are not the only possible interpretations of these provisions, however and, as discussed below, some clarity was eventually provided in a pair of contested merger cases.

\section{Enforcement of the Merger Provisions}

To provide guidance to the business community about its approach to the new law -- and perhaps also to discipline its own enforcement -- the Competition Bureau produced a set of Merger Enforcement Guidelines (MEGs) in 1991 (current version at Canada (2011)). ${ }^{66}$ Modelled on the merger guidelines issued by the U.S. Department of Justice (and later jointly with the Federal Trade Commission), the MEGs have been revised twice, in 2004 and 2011. These guidelines have also reflected current thinking of competition economists and have evolved as new ideas and new enforcement techniques were developed.

For example, over the years techniques applied to define markets have evolved, most notably those associated with the definition of local markets. Perhaps most completely described in

\footnotetext{
${ }^{63}$ Since the effect on post-merger prices is all that matters, only efficiencies affecting marginal costs need be considered. Savings in fixed costs will not normally be relevant under this standard.

${ }^{64}$ This is essentially an application of the approach outlined in famous work by Oliver Williamson (1968).

${ }^{65}$ And these efficiencies could include savings in fixed costs.

${ }^{66}$ For a very complete discussion of the 1991 MEGs by their principle author, see Crampton (1991).
} 
materials from the Superior Propane case, ${ }^{67}$ the methods had been developed through the review of numerous mergers in the retail sector, for example in gasoline, grocery and retail banking markets.

Importantly, the MEGs from their 1991 origins recognized two principle theories of harm that could apply to mergers, each with its own theoretical supports and recommended techniques. The first recognizes the potential for mergers to give the merging firms the power to unilaterally raise price post-merger where by "unilaterally" we mean that the price increases will be profitable for the merging firms even without any accommodating behaviour from remaining rival firms. Concerns about unilateral effects are usually seen to depend on the post-merger market share of the merged firms, as well as the magnitude of entry barriers and other conditions. The second contemplates situations in which the merger could increase the scope for coordinated behaviour among the remaining firms in the market - essentially tacit or even explicit collusion. ${ }^{68}$ When concerns arise about the dangers of coordinated effects, we look to the theory of cartels to see if the conditions for collusion, for example, high levels of market concentration, are met in the market.

In contrast to the U.S. at the time, most of the focus of early merger enforcement under the new law in Canada related to mergers where the principle concern was about potential unilateral effects. $^{69}$ As a result, there was much more attention, for example, paid to the market share of the merged firm in Canada than in the U.S. where the degree of market concentration (often measured by the Herfindahl-Hirshman Index) would get more attention. ${ }^{70}$ Over time this changed and more attention was paid to coordinated effects in Canada. This was reflected in the expanded treatment of coordinated effects in the 2004 revision of the MEGs. In more recent years, there has been an increased focus on unilateral effects on both sides of the border, particularly with respect to mergers in differentiated products industries where the key to the analysis typically lies in the degree to which the merging parties were each other's next best

\footnotetext{
${ }^{67}$ Canada (Commissioner of Competition) v Superior Propane Inc. (CA), 2003 FCA 53, [2003] 3 FC 52.

${ }^{68}$ The first version of the MEGs in 1991, used the term "interdependence" rather than "coordinated effects"; this language was changed in the 2004 revisions.

${ }^{69}$ On the first ten years of enforcement of the new merger provisions, see McFetridge (1998).

${ }^{70}$ The U.S. Merger Guidelines issued in 1982 focused on coordinated effects as the more likely source of harm. In so doing, it drew inspiration from Stigler (1964). Subsequently, in the 1992 U.S. Merger Guidelines the idea of harm coming from unilateral effects was developed.
} 
substitutes pre-merger. Part of the refocus on unilateral effects can possibly be explained by the recognition that many if not most markets involve differentiated products.

The techniques used by modern authorities to evaluate mergers have also improved over time with the influence of economists - particularly with respect to mergers of firms in differentiated products industries. The degree to which one product is viewed as a close substitute for another is now typically measured using the "diversion ratio". ${ }^{71}$ The diversion ratio between two firms, $\mathrm{A}$ and $\mathrm{B}$, measures the fraction of sales lost by one firm when it increases price that flow to the other firm - a quantity clearly related to the cross-elasticity of demand between the goods. To be precise, if $\mathrm{X}_{\mathrm{A}}$ and $\mathrm{X}_{\mathrm{B}}$ define quantities and $\mathrm{P}_{\mathrm{A}}$ and $\mathrm{P}_{\mathrm{B}}$ prices, the diversion ratio from $\mathrm{A}$ to $\mathrm{B}$ would be given by: ${ }^{72}$

$$
D_{A B}=\frac{-\partial X_{B} / \partial P_{A}}{\partial X_{A} / \partial P_{A}}
$$

Simple tests to screen for problematic mergers using diversion ratios have been developed and are routinely used now by the Competition Bureau and other modern agencies. An example is the "upward pricing pressure" (UPP) measure which captures the enhanced incentive of one of the merging firms to raise its price now that some of the lost sales (the fraction measured by the division ratio) will go to its merger partner, earning profits there in proportion to the margin on those sales.

While the UPP captures the incentive to raise price, it does not measure how much higher prices can be expected to be. However, diversion ratios can also be used to quite simply calculate an "indicative price rise" (IPR) if we are prepared to make some assumptions about functional forms and hold rivals' prices constant. ${ }^{73}$

Both the UPP and IPR measures are used for a "first look" at a proposed merger - essentially as screens to select transactions that need closer study. While generally easy to calculate, they leave out too much to be considered a complete analysis. For example these measures implicitly

\footnotetext{
${ }^{71}$ The diversion ratio appears in the 2011 revision of the MEGs.

72 In terms of elasticities, if $\mathrm{e}_{\mathrm{AB}}$ is the cross-elasticity of demand and $\mathrm{e}_{\mathrm{A}}$ the own-price elasticity of demand, we can write: $D_{A B}=\frac{-e_{A B}}{e_{A}} \cdot \frac{X_{B}}{X_{A}}$.

${ }^{73}$ See, e.g., Shapiro (1996).
} 
assume that prices of non-merging firms are held constant, i.e. the measures (unlike merger simulation) fail to capture the full equilibrium impact of a merger. In a market in which prices are strategic complements, these simple measures underestimate the eventual effect on prices.

Developments in empirical industrial organization -- and better data -- have allowed us to estimate systems of demand relationships and measure cross-price effects. This has opened up the possibility of simulating mergers to allow for simple reactions by other firms. ${ }^{74}$ Simulation techniques allow us to combine information on the demands for products (including data on elasticities and cross elasticities) with a theory of market behaviour (most commonly differentiated Bertrand price competition) to build a model of the market in which various tests can be conducted - such as looking for the effects of any particular merger. While competition agencies in many countries, including Canada, are using merger simulations as part of their review of mergers, the techniques are still being refined and tested to assess the accuracy of their predictions. ${ }^{75}$ There is concern, for example, that different functional form assumptions can lead to very different predictions on post-merger prices. ${ }^{76}$

Alternatives to merger simulations using more non-parametric techniques may be available perhaps through the use of natural experiment opportunities. For example, the comparison of prices in markets served by multiple office supply superstores to prices in markets served by one or no such superstores helped to inform market definition and assess the potential for negative effects in the proposed merger of Staples and Office Depot in the United States in $1997 .{ }^{77}$

Merger review is now probably the most economics-intensive area of antitrust enforcement, in part because it is normally so prospective; that is, there are no existing effects to be observed and measured. Rather, economists must predict effects on competition and efficiencies based on an analysis that will normally require that they (i) define markets; (ii) assess the importance of barriers to entry; (iii) contemplate possible theories of harm; (iv) quantify the potential harm to competition, (v) quantify the potential efficiencies; (vi) combine harm and efficiencies into a net effect, allowing for various approaches to the trade-offs; and (vii) assess the potential impacts on

\footnotetext{
${ }^{74}$ For a survey, see Budzinski and Ruhmer (2009).

75 There is an interesting exchange titled "Wither Simulations" on the role of simulations in merger review in a 2004 issue of The Antitrust Source: www.antitrustsource.com (May 2004).

${ }^{76}$ See, for example, Crooke et al (1999).

77 See, for example, Dalkir and Warren-Bolton (2014).
} 
the market of any proposed remedies, such as divestitures. And, given that many reviewable mergers will involve multiple product and geographic markets, all of these tasks may need to be undertaken many times, all with a clock ticking as the merging firms press for clearance to proceed with their transaction quickly.

\section{Important Canadian merger cases}

While the volume of mergers needing detailed evaluation has not been large in Canada, there have been a number of important cases that have revealed much about how officials of the Competition Bureau and judges on the Competition Tribunal see their roles. A few cases have also served to help define key terms in the Act. We briefly mention only a few cases here, focusing largely on those that changed the orientation of competition policy enforcement in Canada or introduced new concepts into merger review.

In the Southam (1992) case involving the merger of newspaper companies, the Bureau and Tribunal had to confront the economics of two-sided markets before there was much of an economics literature on the topic. ${ }^{78}$ As is now well recognized, newspapers compete for both readers in one market and for advertisers in another with network effects operating across those markets.

The Canadian Waste Holdings (2001) case involved the acquisition of a waste disposal site owned by Browning Ferris Industries by Canadian Waste Holdings, a firm that also provided landfill services. ${ }^{79}$ The concern was for a lessening of competition in Greater Toronto Area. The case posed a number of local market definition challenges, combining issues related to the efficient use of exhaustible resources, the differences between Ricardian rents and economic profits and the possible relevance of "cellophane fallacy" arguments to some merger cases. ${ }^{80}$

In the Hillsdown (1992) case involving the merger of two meat rendering companies in Southern Ontario, the Tribunal demonstrated its intention to be forward looking and consider the impact of

\footnotetext{
${ }^{78}$ Canada (Director of Investigation and Research) v. Southam Inc. (1992), 43 C.P.R. (3d) 161 (Comp. Trib.).

${ }^{79}$ Canada (Commissioner of Competition) v. Canadian Waste Holdings Inc., [2001] Comp. Trib.3.

${ }^{80}$ Sanderson and Winter [2002] take issue with the Commissioner's arguments and the Tribunal's decision -- which led to a divestiture - on the grounds that they did not correctly deal with these challenges.
} 
the merger into the future when there is reason to believe that the markets are changing. ${ }^{81}$ In this case, the Tribunal concluded that the merging parties were already moving towards exclusive participation in different markets, suggesting that the merger would not reduce competition from levels that would be observed absent the merger.

Two large cases in which there were important interventions by other branches of government presented themselves toward the turn of the century. Air Canada's acquisition of Canadian Airlines in 2000 was something of a "failing firm" case and was allowed subject to some conditions when the government (through the Minister of Transport) relied on provisions in the Canada Transportation Act to intervene on behalf of the merger This all came on the heels of another government intervention challenging the independence of the Bureau, which occurred in 1998 when the Bureau released the results of its preliminary reviews of the proposed mergers of the Royal Bank of Canada with the Bank of Montreal and the Canadian Imperial Bank of Commerce with the Toronto-Dominion Bank. The Bureau had concluded that there were competition concerns in some markets with both transactions. The scale of the reviews undertaken, under significant time pressure, cannot be overstated. These would have been the two largest mergers in Canadian history, happening at the same time and in mostly the same markets. However, after the Bureau's eleven month review (and after delivering its preliminary conclusions to the banks) the Minister of Finance in December 1998, exercising his authority under the Bank Act, announced that the mergers were not in the public interest and could not proceed. ${ }^{82}$

The Bureau has also show a willingness to consider non-conventional remedies. For example, in Asea Brown Boveri Inc. (1990), involving the acquisition by ABB of the electrical transmission and distribution equipment manufacturing operations of Westinghouse Canada, the remedy included a promise (which was kept) by ABB to secure full duty remission (from the Department of Finance) on all imports of transformers of a certain size for a period of five years. This would

\footnotetext{
${ }^{81}$ Canada (Director of Investigation and Research) v. Hillsdown Holdings (Canada) Ltd. (1992), 41 C.P.R. (3d) 289 (Comp. Trib.).

${ }^{82}$ The review had involved a team of over 100 officers and experts, and had required special funding of $\$ 4$ million from the Treasury Board. See, e.g. Clifford and Rowley (1999).
} 
make import competition much more effective: ${ }^{83}$ To the same end, $\mathrm{ABB}$ also undertook to secure an accelerated reduction in tariffs on imports from the U.S. of smaller transformers.

Air Canada - Gemini (1990) was another consent order with a creative remedy. ${ }^{84}$ The case involved the merger of two airline reservations systems, Reservec (owned by Air Canada) and Pegaus (owned by Canadian Airlines International), creating the Gemini system. To address concerns that the merged system could facilitate coordinated behaviour between the two airlines and discriminate against other airlines, the remedy included of a set of behavioural rules - a sort of regulatory regime not unlike one used in the U.S. and administered there by the Civil Aeronautics Board - as part of the consent order.

\section{A Very Canadian Case: The Welfare Standards and Trade-off Analysis}

Perhaps the most notable of all merger cases under the new law has been the Superior Propane (2003) case. ${ }^{85}$ In defending this merger, the efficiency exemption was invoked by the merging parties and the Tribunal had to address directly the welfare standard to be applied. Despite new arguments from the Commissioner that the appropriate standard is not the total welfare standard, the Tribunal initially took the view that the total welfare standard was exactly the right basis on which to trade off harms to competition and efficiencies. Given evidence that the deadweight loss was much smaller than the accepted efficiencies, the Tribunal rejected the Commissioner's request to block the merger. ${ }^{86}$ On appeal the Federal Court of Appeal disagreed with the Tribunal about the welfare standard, pointing to objectives of the Competition Act other than efficiency (as listed in Section 1.1 of the $A c t$ ). Specifically, the appeal court indicated that the Tribunal should consider any potential negative effects from the redistribution of surplus from consumers to producers. One way to do this, it suggested, was to calculate the relative social

\footnotetext{
${ }^{83}$ Director of Investigation and Research v. Asea Brown Boveri Inc. (1990) 27 C.P.R. (3d) 65.

${ }^{84}$ Director of Investigation and Research v. Air Canada (1990) (a.k.a. "Gemini I") 27 C.P.R. (3d) 476. This is often referred to as the Gemini I case because there was a later case (Gemini II) in which Canadian Airlines asked to vary the consent order to let it out of Gemini so that it might join with American Airlines in its service.

${ }^{85}$ Canada (Commissioner of Competition) $v$ Superior Propane Inc (CA), 2003 FCA 53, [2003] 3 FC 52.

${ }^{86}$ Unfortunately, the correct deadweight loss was not put before the Tribunal for some reason. There was evidence of pre-existing market power - with the potential to transform deadweight losses from small triangles to much larger trapezoids in the familiar diagrams. But this pre-existing market power was not factored into the calculations of deadweight loss. Subsequent work has suggested that, correctly calculated, the deadweight loss and efficiencies would have been of roughly similar magnitudes. See, e.g. See, e.g., M. Sanderson (2002) and Mathewson and Winter (2000).
} 
weights that would balance the harms to consumers with the gains to producers and then to ask how these "balancing weights" would compare to reasonable social weights that we might want to attach to these groups. On its reconsideration of the case, the Tribunal performed this exercise, drawing ideas on social weights from the progressivity of tax schedules, but concluded again that the transaction should be allowed to proceed. On a new appeal, the Federal Court of Appeal accepted this Tribunal decision.

Where this leaves Canada with respect to the welfare standards to be applied in trade-off analyses is unclear; further certainty may require additional jurisprudence. One view, from Ross and Winter (2005), suggests that we are still close to a total welfare standard and that redistribution concerns will likely affect decisions only if the transfers from consumers are particularly large and/or will be borne by vulnerable (likely consumer) groups.

\section{Canadian merger review going forward}

In only the second merger case to go to the Supreme Court under the Competition Act, the Court dramatically increased the importance of economic analysis - particularly quantitative economic analysis -- in merger review. Tervita involved a merger in the hazardous waste landfill market in Northeastern British Columbia. ${ }^{87}$ Somewhat ironically for a case that was appealed all the way to the Supreme Court, this was a transaction so small (C\$6 million) as to fall well below the merger pre-notification thresholds in Canada. There were a number of points made in the Court's decision that will affect merger review going forward, here we comment on two. ${ }^{88}$

First, the Court drew a sharp distinction between qualitative and quantitative evidence, expressing a clear preference for the latter. More than this, it required that any effects that can possibly be quantified must be quantified, perhaps with inadequate recognition that attempts at quantification may not always yield reliable numbers. In its decision, the Court allowed the merger to proceed even given evidence of a likely price increase post-merger and evidence of almost negligible efficiencies. This was, in part, because the Commissioner had not measured the deadweight loss that the price increase would produce - hence the harm to competition was given zero weight and the very small efficiencies won the day. This result will surely result in

\footnotetext{
${ }^{87}$ Tervita Corp. v Canada (Commissioner of Competition) 2015 SCC 3.

${ }^{88}$ For more on this case, see for example, Winter (2015) and Ross (2016).
} 
more extensive quantitative work being conducted much earlier in merger reviews - and much more extensive demands for data made to the merging parties by the Bureau. While this could lead to more complete analyses of the potential costs and benefits of proposed mergers, there is also the danger that the pursuit of false precision could be costly in terms of time and money for the Bureau, and for merging parties.

Second, the Court showed a willingness to grant the Bureau and Tribunal wide latitude in considering how the market would change "but-for" the proposed transaction. Tervita was a "prevent" case: Tervita and the acquired property were not current competitors. The site being acquired (Babkirk) was being set up to provide bioremediation services, not as a competitive landfill. However, Babkirk did have permitting that would allow it to operate a competitive landfill operation if it chose to do so. The theory of harm held that without this transaction the Babkirk site would fail as a bioremediation facility and would then turn to landfill operations and become a new competitor for Tervita. ${ }^{89}$ While this forward-looking approach in considering the market without the merger is in general to be commended, the second-guessing of management's business plans will trouble many economists.

Taking these aspects of the Tervita decision together, economists might be both buoyed and challenged. The Court has clearly elevated the role of economists in merger review by requiring that they measure anything they can and giving them an opening to contemplate a wide variety of "but-for" scenarios in prevent cases. But some will be concerned that in cases in which data are poor and estimation challenging, too much is being demanded of economic analysis.

\section{Conclusions}

This article has reviewed the enormous influence of economic thinking in the development of competition policy over the past 50 years. A natural question is whether the integration of economic foundations into policy in this area is essentially complete. We suggest, in concluding this essay, that it is not. Specific aspects of the law in the three areas that we have reviewed cartels, single-firm conduct, and mergers - must be changed if competition policy is going to rest

\footnotetext{
${ }^{89}$ To be fair, there was some supporting evidence for this conclusion.
} 
on solid economic foundations. In each of the three areas that we have reviewed, we summarize the key points we have outlined and discuss aspects of the law that remain troublesome.

In the area of cartels, we noted that Canadian law has abandoned an old requirement that the anticompetitive effect from collusion be "undue" and moved to a per se rule against coordination of naked cartels. This leaves Canadian law on this point consistent with the law in other jurisdictions. In the same amendment to the Competition Act in 2010, a two-track approach to horizontal cooperation was adopted. This development was in large part a response to submissions by economists on the theme that some pro-competitive coordination, especially in the area of innovation, required coordination among competitors. We reviewed the influence of economic analysis on competition policy in several additional areas related to cartels: the optimality of fines for cartels; screening for cartels using pricing data; the role of facilitating practices in supporting collusion (and the role of competition policy in limiting these practices); and the development of leniency and compliance programs.

Among these dimensions, leniency programs -- as we have noted -- have proven to be remarkably successful in raising enforcement activity in cartels. Economists have a role to play in assessing leniency programs, research that has been undertaken by, for example, Harrington (2010). As he and others have noted, the impact of leniency programs on the observed number of cartels uncovered is the net result of two offsetting effects: for a given number of cartels that form, a greater proportion of the cartels are detected; but the success of the programs will lead to a decrease in the (unobservable) number of cartels formed. Even more important is the role that economists are playing in the design of leniency programs (see Harrington (2008a and 2008b) for early work on this): for example, on the question of who should qualify for leniency? In particular, should a cartel coordinator or instigator be eligible? Some leniency programs offer limited protection not just for the first party coming forward but also for the second (and sometimes more). What is the optimal range of protection that should be offered to the sequence of cartel members seeking leniency, and for how long - as the government gathers information should the leniency program be in effect in any case? Leniency programs will undoubtedly evolve with contributions from economic theory and empirical analysis.

In the area of single firm conduct, a recent court decision is at odds with economics, leaving Canadian competition law with a substantial gap. Practices that substantially lessen competition 
cannot be challenged and remedied because the practices are not "anticompetitive" under the law as it is. Section 791 (b) of the Competition Act requires that a person be engaged in "a practice of anticompetitive acts" for a remedy to be imposed. Section 791 (c) requires that the practice "lessen competition substantially".90 The Federal Court of Appeal in Canada Pipe91 decided that "anticompetitive" in 79 (1) (b) must mean something different than "lessen competition" in 79 (1) (c). A principle of statutory interpretation is that a clause must be interpreted so as to have meaning independent of other clauses; "lessening competition" therefore cannot mean the same thing as "anticompetitive". The court resolved this dilemma by deciding that "anticompetitive" must refer to harm being done to a rival, not to the competitive process.

The decision runs against the principle that the purpose of competition law is not the protection of competitors but rather protection of the competitive process so that the ultimate goal of competition policy, the efficient allocation of resources, is achieved - a principle that Trebilcock (2007) calls "the single greatest advance in thinking in the competition policy field over the past 30 years." Canada Pipe leaves the Abuse of Dominance provision in the Act unable to deal with practices that lessen competition and benefit rivals, rather than harm rivals. Winter (2014) delineates the set of such practices. This gap in the Act is not just a matter of theory. In Visa,92 the Commissioner challenged a practice that is essentially equivalent to the following vertical restraint: a supplier requires that retailers not charge more for the supplier's product than for rivals' products. When imposed by all firms in a market, this restraint eliminates the ability of a supplier to undercut rivals' high prices because rivals' retail prices automatically follow the supplier's retail price downwards if the supplier cuts its wholesale price. Price competition is suppressed completely by the restraint. ${ }^{93}$ The restraint is anticompetitive, but benefits all firms in the market. This gap in Canadian competition law on single firm practices must be filled. ${ }^{94}$ In

\footnotetext{
${ }^{90}$ The precise language is "(c) the practice has had, is having or is likely to have the effect of preventing or lessening competition substantially in a market" (Section 791 (c) of the Competition Act.

${ }^{91}$ Canada (Commissioner of Competition) v Canada Pipe Co., 2006 FCA 233.

${ }_{92}$ Canada (Commissioner of Competition) $v$ Visa Canada Corporation and MasterCard International Incorporated, 2013 Comp.Trib. 10.

${ }^{93}$ In fact, the restraint changes the equilibrium price of the non-cooperative pricing game from the (differentiated) Bertrand price, which is less than the fully collusive price, to a value even greater than the fully collusive price. This is because once the restraint is adopted by all firms in the market, the firms' products are complements rather than substitutes. Non-cooperative pricing among complementary producers always yields prices greater than collusive values, as Cournot (1838) first pointed out. See Carlton and Winter (2017) for development of the idea.

${ }^{94}$ There appears to be some belief among practitioners that the gap has been closed by the Tribunal's 2016 decision in TREB (The Commissioner of Competition v The Toronto Real Estate Board, 2016 Comp. Trib. 8 CT-2011-003).
} 
addition, the Act in this area needs general revision in its language to ease the focus on economic impact rather than legal interpretation of a wide variety of phrases. The various sections of the Act that deal with single firm practices contain different criteria under which practices can be challenged and remedied. These sections include s.75 (refusal to deal), s.76 (price maintenance), s.77 (exclusive dealing, tied selling and market restriction) and s.79 (abuse of dominance).

Section 75 uses the term "adverse effect on competition," rather than "lessening of competition"; only section 79 among these sections contains as a possible criterion the "prevention of competition"; intent or anticompetitive purpose is important in the case law interpreting s.79 but not the interpretation of other sections, and so on. We would suggest than in the next amendment of the Act, these sections be collapsed into one section on single firm practices with a single criterion: the likelihood of substantial lessening or prevention of competition, language that appears through the Act and has a solid legal interpretation. Having a single phrase as the basic criterion would still allow flexibility in the application of the law to different practices, which could be set out in Bureau Guidelines. And it would eliminate the unnecessary gap in Canadian competition policy regarding single-firm practices.

In terms of reliance on quantitative economic analysis, within the area of Canadian law on mergers the pendulum has, ironically, swung too far. In Tervita, the Supreme Court of Canada agreed with a finding of a substantial lessening of competition from a merger in the market for waste disposal servicing oil and gas producers in northeastern B.C. But in the next stage of the merger review process (the balancing of the anticompetitive effect with efficiencies, using essentially the total surplus criterion) the court rejected the Commissioner's entire set of evidence on the basis that the Commissioner had not provided an estimate of the elasticity of demand in the market. The Court argued that the respondents in a merger case do not know the quantitative standard that they must meet in developing quantitative evidence for efficiencies if

It has not. Tervita involved restraints imposed by the Toronto Real Estate Board (TREB) that inhibited the development of online provision of real estate services (virtual office websites). The practice of these restraints harmed the competitors to TREB members who had entered the brokerage market using virtual office websites. Because it involved harm to competitors, TREB is not a test of whether an abuse of dominance that does not harm competitors would be caught by the Competition Act after Canada Pipe. 
the Commissioner has provided only qualitative evidence.95 The decision reflects a lack of appreciation for the difficulties of estimating the elasticity of demand, especially in a market (like the one in which the merger was being challenged) with idiosyncratic demand and transaction-specific pricing. Nor does it recognize that the balancing of quantitative against qualitative evidence is necessary in various areas of the law. ${ }^{96}$

Some competition policy practitioners have called for elimination of the second stage of merger review, which is the balancing of a (proven) lessening of competition against efficiencies. Efficiencies would be recognized instead as one factor in the assessment of the competitive impact of the merger. We suggest instead a re-thinking of the mechanism under which mergers are defended on the basis of efficiencies. When one party in a dispute has quantitative evidence (which is required of respondents under the current practice of merger review) and the other party can adduce only qualitative evidence and is not as well informed, we conjecture the best mechanism within the adversarial process has the party with quantitative evidence present their evidence first. This would allow better communication of the overall evidence to the trier of fact, the court, so that the court can make a judgment. The optimal mechanism for merger review is clearly an issue that deserves more thought, and one on which economists must contribute. Competition law in this area, as in others, continues to evolve and the evolution increasingly involves economic analysis.

\footnotetext{
95 The Court did not explain why knowing the standard the must be met is of any value. The merging parties should simply present their full evidence of efficiencies.

${ }^{96}$ Ross (2016) and Winter (2015) analyze Tervita in more depth.
} 


\section{References}

Aghion, Philippe, and Patrick Bolton (1987) "Contracts as a Barrier to Entry," American Economic Review 77, 388-401.

Aguzzoni, Luca, Gregor Langus, and Massimo Motta (2013) "The Effect of EU Antitrust Investigations and Fines on a Firm's Valuation," The Journal of Industrial Economics 61, 290338.

Allain, Marie-Laure, Marcel Boyer, Rachidi Kotchoni, and Jean-Pierre Ponssard (2015) "Are Cartel Fines Optimal? Theory and Evidence from the European Union," International Review of Law and Economics 42, 38-47.

Allain, Marie-Laure, Marcel Boyer, and Jean Pierre Ponssard (2011) "The Determination of Optimal Fines in Cartel Cases: Theory and Practice," Concurrences - Competition Law Journal 4, 32-40.

Asker, John, and Heski, Bar-Isaac (2014) "Raising Retailers' Profits: On Vertical Practices and the Exclusion of Rivals," American Economic Review 104, 672-686.

Becker, Gary S. (1968) "Crime and Punishment: An Economic Approach,” Journal of Political Economy 76, 169-217.

Bliss, Michael (1973) "Another Anti-Trust Tradition: Canadian Anti-Combines Policy, 18891910," The Business History Review 47, 177-188.

Bliss, Michael (1987) Northern Enterprise: Five Centuries of Canadian Business, Toronto: McClelland and Stewart.

Bork, Robert (1978) The Antitrust Paradox. New York, NY: Free Press.

Bosch, Jean-Claude, and E. Woodrow Eckard Jr. (1991) “The Profitability of Price Fixing: Evidence from Stock Market Reaction to Federal Indictments," The Review of Economics and Statistics 73, 309-317.

Boyer, Marcel, and Rachidi Kotchoni (2015) “How Much Do Cartel Overcharge?” Review of Industrial Organization 47, 119-153.

Boyer, Marcel, Tracy R. Lewis, and Wei Lin Liu (2000) "Setting Standards for Credible Compliance and Law Enforcement," Canadian Journal of Economics 33, 319-340.

Budzinski, Oliver, and Isabel Ruhmer (2009) "Merger Simulation in Competition Policy: A Survey," Journal of Competition Law \& Economics 6, 277-319. 
Canada, Standing Committee on Industry, Science and Technology (SCIST) (2002) Report: A Plan to Modernize Canada's Competition Regime, April.

Canada, Competition Bureau (2011) Merger Enforcement Guidelines (MEGs), at www.competitionbureau.gc.ca/eic/site/cb-bc.nsf/eng/03420.html

Carleton, D. and Winter, R.A. (2017) "Vertical MFNs and no-surcharge rules in Credit Card Markets," at https://ssrn.com/abstract=2982115

Chandler, H. and R. Jackson (2000) "Beyond Merriment and Diversion: the Treatment of Conspiracies under Canada's Competition Act," Round Table on Competition Act Amendments, Insight Conferences, Toronto, May 25.

Chen, Zhiqi, Subhadip Ghosh, and Thomas W. Ross (2015) "Denying Leniency to Cartel Instigators: Costs and Benefits," International Journal of Industrial Organization 41, 19-29.

Clifford, John F., and J. William Rowley (1999) "Canadian Banks: Why the Mega-Mergers were Stopped," Global Competition Review Volume 25, at https://globalcompetitionreview,com/article/1046117/canada-says-no-to-banking-mega-mergers

Competition Bureau, Canada (2015) "Corporate Compliance Programs," Available at: http://www.competitionbureau.gc.ca/eic/site/cb-bc.nsf/eng/03927.html.

Competition Bureau, Canada (2010) "Leniency Program," Available at: http://www.competitionbureau.gc.ca/eic/site/cb-bc.nsf/eng/03288.html.

Connor, John M. (2007) Global Price Fixing. New York, NY: Springer.

Connor, John M. (2014) Price-Fixing Overcharges: Revised 3rd Edition. Available at: https://papers.ssrn.com/sol3/Papers.cfm?abstract_id=2400780.

Connor, John M., and Robert H. Lande (2012) "Cartels as Rational Business Strategy: Crime Pays," Cardozo Law Review 34, 427 - 489.

Cournot, Antoine A. (1838) Researches on the Mathematical Principles of the Theory of Wealth Crampton, Paul S. (1991) "Canada's New Merger Enforcement Guidelines: A 'Nuts and Bolts' Review," Antitrust Bulletin 36, 883-972.

Crooke, Philip, Luke Froeb, Steven Tschantz, and Gregory J. Werden (1999) "Effects of Assumed Demand Form on Simulated Postmerger Equilibria," Review of Industrial Organization 15, 205-217.

Csorgo, Lilla (2009) “Canada's Draft Abuse of Dominance Guidelines: A Comparative Look," Working Paper, Competition Bureau. 
Dalkir, Serdar, and Frederick R. Warren-Bouton (2014) "Prices, Market Definition and the Effects of Merger: Staples - Office Depot (1997)," Chapter 6 in The Antitrust Revolution: Economics, Competition, and Policy (6 $6^{\text {th }}$ Edition), John E. Kwoka Jr. and Lawrence J. White (eds.), New York, NY; Oxford University Press.

Dixit, Avinash (1980) “The Role of Investment in Entry-Deterrence," The Economic Journal 90, 95-106.

Economic Council of Canada (1969) Interim Report on Competition Policy. Ottawa:

Queen's Printer.

European Commission (2010) "Guidelines on Vertical Restraints".

Günster, Andrea Maria; and van Dijk, Mathijs (2016) "The Impact of European Antitrust Policy: Evidence from the Stock Market," International Review of Law and Economics 46, 20-33.

Halladay, Casey W. (2012) "The Origins of Canada's Cartel Laws," Canadian Competition Law Review 25, 157-163.

Harrington, Joseph E. (2008a) "Detecting Cartels," In Handbook in Antitrust Economics, 213258, Paolo Buccirossi (ed), Cambridge, MA: MIT Press.

Harrington, Joseph E. (2008b) “Optimal Corporate Leniency Programs,” The Journal of Industrial Economics 56, 215-246.

Harrington, Joseph E. (2010) "Leniency Programs: Past Experience and Future Challenges," presentation to Instituto Milenio SCI, December 13, 2010.

Holmstrom, Bengt (1979) "Moral Hazard and Observability," The Bell Journal of Economics 10, 74-91.

Hüschelrath, Kai, Nina Leheyda, and Patrick Beschorner (2011) "The Deterrent Effect of Antitrust Sanctions: Evidence from Switzerland," Antitrust Bulletin 56, 427-460.

International Competition Network "Setting of Fines for Cartels in ICN Jurisdictions," Report to the $7^{\text {th }}$ ICN Annual Conference in Kyoto, April 2008, at http://www.internationalcompetitionnetwork.org/uploads/library/doc351.pdf.

Ippolito, Pauline (1991), "Resale Price Maintenance: Empirical Evidence from Litigation," The Journal of Law \& Economics Vol. 34, No. 2 (Oct.), pp. 263-294

Isfeld, Gordon (2012) “Competition Bureau Made 'Lasting Impression' with Tough-Talking Aitken At Helm", Financial Post September 20, 2012, at http://business.financialpost.com/news/fp-street/competition-bureau-made-lasting-impressionwith-tough-talking-aitken-at-helm. 
Jing, Ran, and Ralph A. Winter (2013) "Exclusionary Contracts," Journal of Law, Economics and Organization 40, 833-867.

Joskow, Paul L. (1987) “Contract Duration and Relationship-Specific Investments: Empirical Evidence from Coal Markets," American Economic Review 76, 168-85.

Julien, Bruno, and Patrick Rey (2007) "Resale Price Maintenance and Collusion," RAND Journal of Economics 38, 983-1001.

Kaplow, Louis and S. Shavell (2001), "Any Non-welfarist Method of Policy Assessment Violates the Pareto Principle," Journal of Political Economy, Vol.109, 281-286.

Kennish, Tim, and Thomas W. Ross (1997) "Toward a New Canadian Approach to Agreements between Competitors," Canadian Business Law Journal 28, 22-68.

Klein, Benjamin (2009), "Competitive Resale Price Maintenance in the Absence of Free-riding," Antitrust Law Journal Vol. 76, No. 2, pp. 431-481

Klein, B. and K. Murphy (1988) 'Vertical Restraints as Contract Enforcement Mechanisms', Journal of Law and Economics, 31, 265-298.

Klemperer, Paul (1987) “The Competitiveness of Markets with Switching Costs,” Rand Journal of Economics 18, 138-150.

Kolasky, William J., and Andrew R. Dick (2003) "The Merger Guidelines and the Integration of Efficiencies into Antitrust Review of Horizontal Mergers," Antitrust Law Journal 71, 207-252.

Marvel, Howard P. (1982) “Exclusive Dealing,” Journal of Law and Economics 25, 1-25.

Mathewson, G. Franklin, and Ralph A. Winter (1984) "An Economic Theory of Vertical Restraints," Rand Journal of Economics 15, 27-38.

Mathewson, G. Franklin, and Ralph A. Winter (2000) "The Analysis of Efficiencies in Superior Propane: Correct Criterion Incorrectly Applied," Canadian Competition Record 20, 88-97.

McFetridge, Donald G. (1998) "Merger Enforcement under the Competition Act after Ten Years," Review of Industrial Organization 13, 25-56.

Morrow, Claude (1990) "Resale Price Maintenance under Review," Canadian Competition Policy Record 11, 39-49.

Motta, Massimo, and Michele Polo (2003) "Leniency Programs and Cartel Prosecution," International Journal of Industrial Organization 21, 347-379. 
O'Brien, Ann (2008) "Cartel Settlements in the US and EU: Similarities, Differences and Remaining Questions," In 13th Annual EU Competition Law and Policy Workshop, Florence, Italy.

Overstreet, Thomas R. Jr (1983) "Resale Price Maintenance: Economic Theories and Empirical Evidence," Bureau of Economics Staff Report to the Federal Trade Commission.

Posner, Richard A. (1971) “A Program for the Antitrust Division," University of Chicago Law Review 38, 500-536.

Rasmusen, Eric B., J. Mark Ramseyer, and John Shepard Wiley Jr (1991) "Naked Exclusion," American Economic Review 81, 1137-1145.

Rey, Patrick (2012) “Vertical Restraints - an Economic Perspective," Toulouse Working Paper.

Rey, Patrick and Jean Tirole (1986) "The Logic of Vertical Restraints," American Economic Review 76, 921-939.

Rey, Patrick and Thibaud Vergé (2010) "Resale Price Maintenance and Interlocking Relationships," Journal of Industrial Economics 58, 928-961.

Rogers, C. Paul III (1996) "Restraints on Alienation in Antitrust Law: A Past with No Future," Southern Methodist Law Review 49, 497-524.

Ross, Thomas W. (2016) "Competitive Effects and Efficiencies: The Canadian Supreme Court's Decision in Tervita," Competition Law \& Policy Debate 2, 54-63.

Ross, Thomas W. (1998) "Introduction: The Evolution of Competition Law in Canada," Review of Industrial Organization 13, 1-23.

Ross, Thomas W. (1991) "Proposals for a New Canadian Competition Law on Conspiracy," Antitrust Bulletin 36, 851-882.

Ross, Thomas W., and Ralph A. Winter (2005) "The Efficiency Defense in Merger Law: Economic Foundations and Recent Canadian Developments," Antitrust Law Journal 72, 471503.

Sanderson, Margaret (2002) "Competition Tribunal's Redetermination Decision in Superior Propane: Continued Lessons on the Value of the Total Surplus Standard," Canadian Competition Record 21, 1-5.

Sanderson, Margaret, and Ralph A. Winter (2002) "Geographic Market Definition in Canadian Waste Services," Canadian Competition Record 21, 112-125. 
Segal, Ilya, and Michael Whinston (2000) "Exclusive Contracts and Protection of Investments," RAND Journal of Economics 31, 603-633.

Segal, Ilya, and Michael Whinston (2000) "Naked Exclusion: Comment," American Economic Review 90, 296-309.

Shapiro, Carl (1996) “Mergers with Differentiated Products," Antitrust 10, 23-30.

Shavell, Steven (1979) "Risk Sharing and Incentives in the Principal and Agent Relationship," The Bell Journal of Economics 10, 55-73.

Spagnolo, Giancarlo (2004) "Divide et Impera: Optimal Deterrence Mechanisms against Cartels (and Organized Crime)," CEPR Discussion Papers 4840.

Spagnolo, Giancarlo (2008) "Leniency and Whistleblowers in Antitrust," In Handbook of Antitrust Economics, 259-304, Paolo Buccirossi (ed.), Cambridge, MA: MIT Press.

Stanbury, W. T., and G. B. Reschenthaler (1980) "Reforming Canadian Competition Policy: Once More unto the Breach," Canadian. Business Law Journal 5, 381-437.

Stigler, George J. (1964) “A Theory of Oligopoly,” Journal of Political Economy 72, 55-69.

Storli, Espen (2014). "Cartel Theory and Cartel Practice: The Case of the International Aluminum Cartels, 1901-1940," Business History Review 88, 445-467.

Telser, Lester G. (1960) "Why Should Manufacturers Want Fair Trade?” The Journal of Law and Economics 3, 86-105.

Thompson, John S., and David L. Kaserman (2001) "After the Fall: Stock Price Movements and the Deterrent Effect of Antitrust Enforcement," Review of Industrial Organization 19, 329-334.

Trebilcock, Michael (2007) “Abuse of Dominance: A Critique of Canada Pipe," Canadian Competition Record Summer, 1-13.

United States, Department of Justice and Federal Trade Commission (2010), Horizontal Merger Guidelines, at www.ftc.gov/sites/default/files/attachments/merger-review/100819hmg.pdf

Warner, Presley L., and Michael J. Trebilcock (1992) "Rethinking Price-Fixing Law," McGill Law Journal 38, 679-723.

Williamson, Oliver E. (1968) "Economies as an Antitrust Defense: The Welfare Tradeoffs," American Economic Review 58, 18-36.

Winter, Ralph A. (1993) "Vertical Control and Price versus Non-Price Competition," Quarterly Journal of Economics 108, 61-76. 
Winter, Ralph A. (2009) “Antitrust Restrictions on Single Firm Strategies," (Presidential Address), Canadian Journal of Economics 42, 1207-1239.

Winter, R. A. (2014), "The Gap in Canadian Competition Law Following Canada Pipe", Canadian Competition Law Review 27, No.2, 292-321.

Winter, Ralph A. (2015) "Tervita and the Efficiency Defense in Canadian Merger Law," Canadian Competition Law Review 28, 145-172. 